\section{АНАЛІЗ РОЗВИТКУ СУЧАСНИХ ТЕХНОЛОГІЙ МОБІЛЬНОГО ЗВ'ЯЗКУ}

Анотаиія: В статі проведено аналіз використання технологій мобільного зв 'язку різних поколінь. Розглянуто розвиток стандартів та протоколів швидкісного доступу до інформаиії системи стільникового зв'язку. Показано, етапи впровадження та перетворення різних технологій.

Ключові слова: технології, стандарти, протоколи мобільного зв'язку, мобільні мережі, стільниковий зв'язок.

\section{Вступ}

Розвиток бездротових технологій передачі даний призводить до збільшення швидкості передачі інформації через мобільні пристрої. В зв'язку з цим появляються нові технології та стандарти для систем радіозв'язку. Телекомунікаційні компанії які займаються зв'язком змушенні забезпечувати перехід на нові сучасні технології. При цьому повинне забезпечуватися також функціонування технологій, що працювали раніше. В зв'язку з цим потрібно провести детальний аналіз стану технологій, що дозволяють збільшити швидкість передачі інформації по бездротовому зв'язку. Результати аналізу дозволять провести прогнозування впровадження наступного покоління стандартів стільникового зв'язку[1-3].

\section{Перехід систем стільникового зв'язку з аналогових до цифрових}

Перші системи стільникового зв'язку були аналоговими, а для усіх аналогових пристроїв використовується частотна модуляція для передачі мови та частотна модуляція для передачі інформації управління. Для передачі інформації різноманітних каналів використовуються різні частини спектру частот (FDMA), 3 полосами каналів в різних стандартах від 12,5 до 30 кГц. Тому було виділено основний недолік аналогових систем - відносно низька ємність, яка $є$ прямим наслідком недостатньо раціонального використання виділеної полоси частот при частотному розподілі каналів[2-4].

Перехід до цифрових систем стільникового зв'язку стимулювався також широким впровадженням цифрової техніки в зв'язок в цілому і в значній мірі був забезпечений розробкою низько-швидкісних методів кодування і появою надмініатюрних інтегральних схем для цифрової обробки сигналів. Саме тому, в різних країнах почали впроваджувати власні системи зв'язку (табл. 1)[2-5]

() Я. І. Корнага, Я. Є. Горбунов
Аналогові системи зв'язку різних країн

\begin{tabular}{|l|c|c|}
\hline \multicolumn{1}{|c|}{ Системи зв’язку } & Країни & Діапазон \\
\hline $\begin{array}{l}\text { Advanced Mobile Phone } \\
\text { Service (AMPS) }\end{array}$ & $\begin{array}{c}\text { США, Канада, Центральна } \\
\text { і Південна Америка, Австралії }\end{array}$ & 800 МГц \\
\hline $\begin{array}{l}\text { Total Access Communications } \\
\text { System (TACS) }\end{array}$ & $\begin{array}{c}\text { Англія, Італія, Іспанія, } \\
\text { Австрія, Ірландія, Японія }\end{array}$ & $900 \mathrm{MГц}$ \\
\hline $\begin{array}{l}\text { Nordic Mobile Telephone } \\
\text { (NMT-450, NMT-900) }\end{array}$ & Скандинавія та ін. & 450,900 МГц \\
\hline C-450 & Німеччина та Португалія & 450 МГц \\
\hline $\begin{array}{l}\text { Radio Telephone Mobile } \\
\text { System (RTMS) }\end{array}$ & Італія & 450 МГц \\
\hline Radiocom +2000 & Франція & $170,200,400 \mathrm{MГц}$ \\
\hline $\begin{array}{l}\text { Nippon Telephone and } \\
\text { Telegraph system (NTT) }\end{array}$ & Японія & $800 \ldots 900 \mathrm{MГц}$ \\
\hline
\end{tabular}

Поширеність аналогових стандартів призвела до унеможливлення прямого впровадження цифрових технологій, тому наприклад у США була прийнята дворежимна аналого-цифрова система, що дозволяла поєднувати роботу аналогової і цифрової систем в одному і тому ж діапазоні. У Європі ситуація ускладнювалася наявністю багатьох несумісних систем, тому було розроблено загальноєвропейський стандарт GSM. Згодом було розроблено пакетний радіозв'язок GPRS завдяки надбудові над GSM та появилась тарифікація за обсягом інформації, а не за часом. Зміна способу кодування для передачі більшого об'єму інформації в GPRS призвела до появи EDGE. Також появилась технологія, що забезпечувала передачу комунікаційних пакетів (XRTT)[3-7].

\section{Модифікація цифрових систем стільникового зв'язку}

\section{3 третього до четвертого покоління}

Мобільний зв'язок третього покоління (3G) будується на основі пакетної передачі даних на частотах сантиметрового діапазону 2 ГГц, передаючи дані зі швидкістю до 3,6 Мбіт. Входить 5 стандартів:

-UMTS/W-CDMA

- CDMA2000/IMT-MC,

-TD-CDMA/TD-SCDMA,

- DECT,

-UWC-136. 
Найбільшого поширення отримали два стандарти: UMTS і CDMA2000, в основі яких лежить технологія множинного доступу з кодовим поділом каналів CDMA, що дозволяє перехід від вузькосмугових систем з кодовим поділом каналів. Технологія UMTS розроблена для модернізації мереж GSM і отримала широке поширення не тільки в Європі, але і в багатьох інших регіонах світу. Робота по стандартизації UMTS координується міжнародною групою 3GPP (Third Generation Partnership Project), а по стандартизації CDMA2000 - міжнародною групою 3GPP2 (Third Generation Partnership Project 2)[2-7].

У мережах $3 \mathrm{G}$ забезпечується надання двох базових послуг: передача даних і передача голосу. Згідно регламентам ITU (International Telecommunications Union ) мережі 3G повинні підтримувати наступні швидкості передачі даних:

- для абонентів з високою мобільністю (до 120 км/год) - не більше 144 кбіт/с;

- для абонентів 3 низькою мобільністю (до 3 км/год) - 384 кбіт/с;

- для нерухомих об’ єктів - 2048 Кбіт/с.

Крім основних технологій організації мобільних мереж були розроблені ще модифіковані методи передачі даних

- HSPA (High Speed Packet Access) - технологія бездротового широкосмугового радіозв'язку, що використовує пакетну передачу даних і $є$ надбудовою до мобільних мереж WCDMA/UMTS. Швидкість передачі становить до 14,4 Мбіт/с.

- HSUPA (High-Speed Uplink Packet Access) - протокол передачі даних сімейства НSPA. Швидкість передачі становить до 5,76 Мбіт/с.

- HSDPA (High-Speed Downlink Packet Access) - протокол передачі даних 3 сімейства HSPA. Швидкість передачі становить до 42 Мбіт/с.

- HSPA+ (Evolved High-Speed Packet Access), - протокол оснований на еволюції HSPA. Швидкість передачі становить до 42,2 Мбіт/с.

Після розвитку систем передачі даних на основі технологій третього покоління розвився стандарт бездротової передачі четвертого покоління (4G). Для цього було розроблено стандарт LTE ( Long-Term Evolution), який був заснований на основі мережевих технологій GSM / EDGE і UMTS / HSPA, збільшуючи пропускну спроможність і швидкість за рахунок використання нового радіо інтерфейсу та модифікації ядра мережі. У різних країнах використовуються різні частоти і смуги для LTE, в зв'язку з цим для підключенні потрібні тільки багатодіапазонні телефони. Хоча маркування $4 \mathrm{G}$ використовується стільниковими операторами і виробниками телефонів, LTE не задовольняє технічним вимогам, які консорціум 3GPP прийняв для нового покоління стільникового зв'язку, а також вимогам, які були спочатку встановлені Міжнародним союзом електрозв'язку. Однак, внаслідок маркетингового тиску, а також значних поліпшень, як WiMAX, HSPA + та LTE змогли внести в початкову версію технології 3G, MCE прийняв рішення, що LTE й інші вищезгадані технології можуть маркуватися як 4G. Стандарт LTE Advanced формально задовольняє початковим вимогам MCE певним в специфікації IMT Advanced і щоб відрізнити його від поточної 4G технології, MET визначив LTE Advanced i WiMAX-Advanced, як «True 4G»[5-8]

Основною ідеєю LTE $є$ мінімізація кількості вузлів. Тому розроблювачі вибрали одновузлову архітектуру. Нова базова станція складніша, ніж Node B в WCDMA/HSPA мережі радіодоступу, і називається ENB. Високі пікові швидкості й зменшений час відгуку в мережах LTE дозволяють забезпечити підтримку додатків реального часу, таких, як геймінг й IPTV. У цій технології буде використовуватися IPv6, що дає змогу збільшити число IP-адрес. IPv6 усуває необхідність перетворення мережних адрес (NAT).

Порівняння різних технологій розвитку мобільного зв'язку дає змогу зробити прогноз подальших тенденцій. Для цього порівняємо всі покоління (табл. 2.)[5-8]

Таблиия 2

Порівняння різних поколінь технологій мобільного зв'язку

\begin{tabular}{|c|c|c|c|c|c|}
\hline Покоління & Реалізація & $\begin{array}{c}\text { Швидкість } \\
\text { передачі }\end{array}$ & $\begin{array}{c}\text { Стандарти } \\
\text { та технології }\end{array}$ & $\begin{array}{l}\text { Частотний } \\
\text { діапазон }\end{array}$ & Сервіси \\
\hline $1 \mathrm{G}$ & 1984 & 1,9 Кбіт/с & $\begin{array}{c}\text { AMPS, TACS, } \\
\text { NMT }\end{array}$ & $\begin{array}{c}170,200,400, \\
450,800^{*}, 900^{*} \\
\text { МГц }\end{array}$ & $\begin{array}{l}\text { Аналоговий } \\
\text { стандарт, мовні } \\
\text { повідомлення }\end{array}$ \\
\hline $2 \mathrm{G}$ & 1991 & $\begin{array}{c}\text { 9,6-14,4 } \\
\text { Кбіт/c }\end{array}$ & $\begin{array}{c}\text { TDMA, } \\
\text { CDMA, GSM, } \\
\text { PDC }\end{array}$ & \multirow[t]{2}{*}{$\begin{array}{l}\text { 900/1800 МГц, } \\
850 / 1900 \text { МГц }\end{array}$} & $\begin{array}{l}\text { Цифровий } \\
\text { стандарт, під- } \\
\text { тримка SMS }\end{array}$ \\
\hline $2,5 \mathrm{G}$ & 1999 & $\begin{array}{c}115-385 \\
\text { Кбіт/с }\end{array}$ & GPRS, EDGE & & \begin{tabular}{|l} 
Пакетна пере- \\
дача даних, \\
збільшення \\
швидкості
\end{tabular} \\
\hline $3 \mathrm{G}$ & 2002 & 3,6 Мбіт/c & $\begin{array}{l}\text { WCDMA, } \\
\text { CDMA2000, } \\
\text { UMTS }\end{array}$ & \multirow[t]{2}{*}{$\begin{array}{c}850,900,1700, \\
1900,2100 \\
\text { МГц }\end{array}$} & $\begin{array}{l}\text { Збільшення } \\
\text { ємності та } \\
\text { швидкості }\end{array}$ \\
\hline $3,5 \mathrm{G}$ & 2007 & 42 Мбіт/c & $\begin{array}{c}\text { HSDPA, } \\
\text { HSUPA, HSPA, } \\
\text { HSPA+ }\end{array}$ & & \begin{tabular}{|l|} 
Збільшення \\
швидкостей \\
3-го покоління
\end{tabular} \\
\hline
\end{tabular}


Закінчення табл. 2

\begin{tabular}{|c|c|c|c|c|c|}
\hline Покоління & Реалізація & $\begin{array}{c}\text { Швидкість } \\
\text { передачі }\end{array}$ & $\begin{array}{c}\text { Стандарти та } \\
\text { технології }\end{array}$ & $\begin{array}{c}\text { Частотний діа- } \\
\text { пазон }\end{array}$ & Сервіси \\
\hline $4 \mathrm{G}$ & 2010 & $\begin{array}{c}100 \text { Мбіт/c- } \\
1 \text { Гбіт/c }\end{array}$ & LTE & $\begin{array}{c}450 \text { МГц, 1,5- } \\
13,6 \text { ГГц }\end{array}$ & $\begin{array}{l}\text { IP-орієнтована } \\
\text { мережа, під- } \\
\text { тримка муль- } \\
\text { тимедіа. }\end{array}$ \\
\hline $5 \mathrm{G}$ & $<2020$ & 7,5 Гбіт/с & МІМО & 28 ГГц & \\
\hline
\end{tabular}

\section{Подальший розвиток мобільних технологій}

Технології для мереж 5 покоління 5G станом на початок 2016 року перебувають у стані розробки. Основним розробником є компанія Нuawei. Основним завданням для мереж п'ятого покоління стане розширення спектра використовуваних частот і збільшення ємності мереж. Очікується, що нова технологія вирішить задачу, над якою працюють всі оператори у світі, - підвищення ефективності мережевої інфраструктури.

В кінці 2015 року компанією Samsung були проведені попередні польові випробування здатностей мережі нового покоління. В результаті стало відомо, що $5 \mathrm{G}$ дозволяє передавати дані зі швидкістю 7,5 Гбіт/сек в лабораторних умовах. При проведенні аналогічних випробувань під час руху швидкість впала до 1,2 Гбіт/сек, причому швидкість станції 3 прийомним обладнанням становила всього близько 100 км/год на відрізку шляху в 4,35 км. Ці випробування проводилися на частоті 28 ГГц.

Достеменно невідомо, які саме технології будуть використовуватися в даному поколінні, але існує думка, що $5 \mathrm{G}$ гарантовано буде мати в своїй основі технологію MIMO (Multiple-Input-Multiple-Output), яка вже використовується в технології LTE. На відміну від колишніх систем стільникового зв'язку, LTE може бути швидко розгорнута в різних частотних діапазонах. Пропускна здатність може бути збільшена шляхом розширення смуги частот або підвищення випромінюваної потужності. Проте, застосовність цих методів обмежена через вимоги біологічного захисту, обмеженої потужності джерела живлення (в мобільних пристроях) і електромагнітної сумісності. Тому якщо в системах зв'язку ці підходи не забезпечують необхідну швидкість передачі даних, то ефективним може виявитися застосування адаптивних антенних решіток з слабо корельованими антенними елементами, тобто МIMO. МІМО є методом просторового кодування сигналу, що дозволяє збільшити смугу пропускання каналу, в якому передача даних та обмін даних здійснюються системами 3 декількох антен. Передають $і$ приймальні антени розносять так, щоб кореляція між сусідніми антенами була слабкою (рис. 1.)

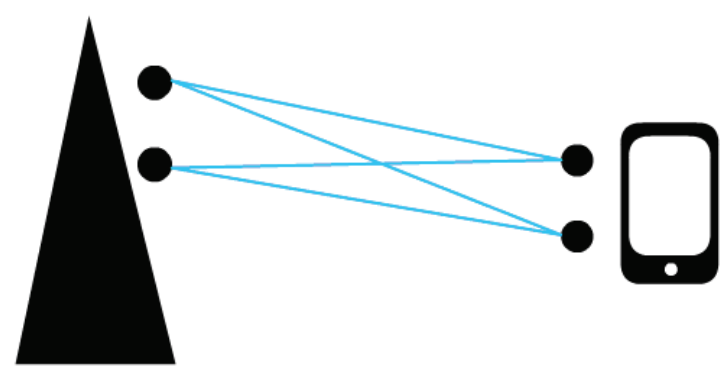

Рис. 1. Принцип роботи МIMO

Можливостями 5G мережі можна буде скористатися не тільки за допомогою мобільного телефону, але також за допомогою ноутбука, нетбука, камери, фіксованих бездротових терміналів й інших пристроїв, орієнтованих на використання мобільного широкосмугового доступу, тому кількість абонентів мобільного зв'язку буде невпинно зростати (рис. 2.).

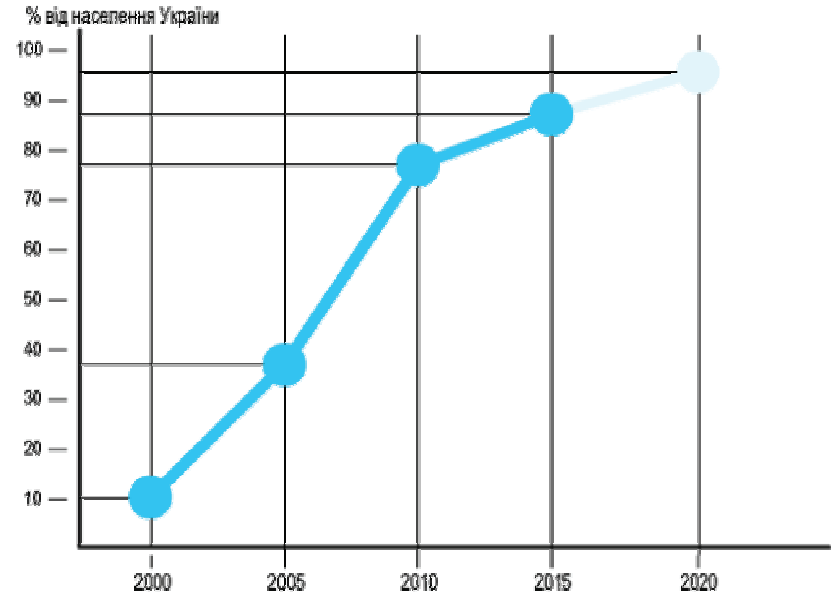

Рис. 2. Графік зростання кількості абонентів 


\section{Висновки}

За останні 30 років мобільний зв'язок перетворився зі звичайного примітивного засобу зв'язку у такий, що базується на множині високошвидкісних технологій, які здатні значно полегшити використання інтернету в житті людей. Нові покоління стандартів стільникового зв'язку з'являються доволі часто: $1 \mathrm{G}$ (NMT) 1979 рік, 2G (GSM) 1991 рік, 3G (W-CDMA/FOMA) 2001 рік, та 4G (LTE) 2008 рік. Початок впровадження технології 5G в Свропі відбудеться до 2020 року, а в Україні через 10 років, а технологія MIMO дозволить використовувати LTE в різних частотних діапазонах

\section{Список використаних джерел}

1. Тихвинский В. О., Терентьев С. В., Юрчук А. Б. Сети мобильной связи LTE. Технологии и архитектура -2010.

2. Бабков В. Ю. Вознюк М. А. Михайлов П. А. Сети мобильной связи. Частотнотерриториальное планирование - 2006.

3. Гельгор А. Л., Попов Е. А. Технология LTE мобильной передачи данных 2011

4. Кааранен X., Ахтиайнен А. Сети UMTS. Архитектура, мобильность, сервисы. $-2007$.

5. Рашич А. В. Сети беспроводного доступа WiMAX - 2011.

6. Карташевский В .Г. Сети подвижной связи - 2010

7. Гепко И. А., Олейник В. Ф., Чайка Ю. Д., Бондаренко А. В. Современные беспроводные сети: перспективы развития - 2009

8. Сюваткин В. C. WiMAX-технология беспроводной связи теоретические основы, стандарты, применение - 2005 .
УДК 004.042

Т. А. Ліхоузова, П. В. Чумаченко

\section{ОГЛЯД КОНЦЕПЦЇ̈ МЕРЕЖ ДОСТАВКИ КОНТЕНТУ}

Анотаиія: Мережі доставки контенту (CDN) спрямовані на подолання обмежень, що властиві Інтернету. Дано короткий огляд основних особливостей механізму роботи $C D N$, наведено його типову архітектуру, охарактеризовано основні типу контенту та сервісів, з якими працює ия технологія. Також розглянуто основні підходи, щяо використовуються механізмом марирутизаиії запитів $C D N$, і характеристики, на основі яких обирається найоптимальніший шиях.

Ключові слова: Мережі доставки контенту, $C D N$, маршрутизаиія запитів.

\section{Вступ}

Комерційний успіх Інтернет- та електронних послуг, разом зі швидко зростаючим використанням комплексного медіа-контенту он-лайн, проклав шлях для народження та розповсюдження мереж доставки контенту (CDN). Інтернеттрафік часто стикається з труднощами продуктивності. Нагальна потреба його користувачів у гарантіях якості викликала необхідність вивчати і розвивати нові мережеві архітектури і технології, щоб покращити якість сприйняття користувача, при цьому знижуючи затрати постачальників.

\section{Постановка задачі}

У наш час CDN підтримують доставку будь-якого типу динамічного контенту, включаючи різні форми інтерактивного медіа-стрімінгу. Провайдери CDN це компанії, що надають свої сервери для розміщення на них контенту третіх осіб, створюючи дзеркала або дублюючи цей контент на кілька серверів по всьому світі і перенаправляючи запити користувачів на «найкращі репліки» (наприклад, найближча репліка, або та, чия затримка буде мінімальною). Тому при створенні повноцінної $\mathrm{CDN}$-системи необхідно вирішити ряд технічних проблем: який тип контенту буде зберігатись на певному сервері CDN, як саме контент буде підтримуватись в актуальному стані, яка саме копія стане «найкращою реплікою» для кожного окремого користувача, які механізми необхідно використати, аби перенаправляти користувачів до цієї репліки. Правильне розміщення дублюючих серверів скорочує шлях від серверів до клієнтів, таким чином знижуючи ризик виникнення проблеми забивання каналу в неорганізованому середовищі мережі Інтернет. Механізм перенаправлення запитів встановлюється на рівні маршрутизаторів для забезпечення пошуку найбільш підходящої репліки (C) Т. А. Ліхоузова, П. В. Чумаченко 